\title{
Historical Financial Information: An Empirical Study on the First Time Adoption of IFRS in Greece
}

\author{
Stamatios Dritsas ${ }^{1} \&$ George Petrakos ${ }^{1}$ \\ ${ }^{1}$ School of Economics and Public Administration, Panteion University, Athens, GR \\ Correspondence: George Petrakos, Dept. of Public Administration, Panteion University, 136 Sygrou Ave., 17671, \\ Athens, Greece. Tel: 030-210-920-1637. E-mail: petrakos@ panteion.gr
}

Received: May 30, 2014

Accepted: June 17, 2014

Online Published: July 25, 2014

doi:10.5539/ibr.v7n8p47

URL: http://dx.doi.org/10.5539/ibr.v7n8p47

\begin{abstract}
In 2004, the Greek Commercial Law incorporated the European Union (EU) regulation regarding the mandatory implementation of International Financial Reporting Standards (IFRS), by all companies listed in Athens Stock Exchange (ASE), for financial years starting January $1^{\text {st }}$, 2005. This structural evolution in the accounting regulation framework in Greece resulted in substantial changes in the historical financial information provided by the Greek listed companies. The aim of this paper is to identify significant differences between the IFRS and the Greek General Accepted Accounting Principles (or Greek GAAP). Based on the results of the nonparametric statistical analysis, significant differences were noted in a number of areas of financial statements. Furthermore, we detected the areas of financial statements provided by Greek companies where differences have had major impact.
\end{abstract}

Keywords: financial reporting, financial statements, Greek General Accepted Accounting Principles (Greek GAAP), International Financial Reporting Standards (IFRS), nonparametric statistics

\section{Introduction}

The European Parliament and the Council of 19 July 2002 decided about the Application of International Accounting Standards or IAS (EC No 1606/2002), for companies that are listed in stock exchanges within the European Union (EU). The new regulation requires all public interest entities listed in EU to prepare and publish financial statements on the basis of accounting standards issued by International Accounting Standards Board (IASB), after processing by EU (Jaruga et al., 2007). The adoption of IAS by the EU was formally approved in July 2003. Member states could apply the mandatory adoption to a wider group of companies and their financial statements (Whittington, 2005). The mandatory adoption of IFRS was directly applicable to public interest entities from 1 January 2005.

Greece incorporated the aforementioned EU requirements in its Corporate Law 2190/1920 in 2004, according to which companies listed in Athens Stock exchange published for the first time financial statements under IFRS for the financial year 2005. Promptly after the first time adoption of IFRS by the public interest entities, the skepticism regarding the appropriateness of financial information included in the Greek statutory financial statements, moved beyond the group of listed companies; it was extended to all Greek limited liability companies under the legal form of Société Anonymes (SA), expanding concerns over the quality of financial information reflected in financial statements, as well as their value as a tool for corporate decision making. Nowadays, the current economic crisis brings back the concerns regarding the total replacement of Greek GAAP by IFRS to all Greek SAs. Furthermore, the main points of the discussion have shifted to subjects like the risks related to the business environment and the ways these risks are imprinted in the financial statements of Greek companies.

This paper attempts to identify significant differences between IFRS and statutory financial statements by selecting and studying several important financial ratios. Data was selected by using stratified random sampling from the population of Greek companies listed in ASE, in all sectors excluding financial services, manufacturing, and pure commercial companies. Statistical data analysis based on nonparametric inferential methods was carried out. 


\section{Literature Review}

Recently, there is an increasing number of studies regarding the adoption of IFRS in EU countries and its impact on the quality of the historical financial information in each Member State.

Terzi, Oktem and Sen (2013) studied the impact of adopting IFRS on listed companies in Turkey. Their study was based on the examination of specific frequently used financial ratios related to financial statements of 140 manufacturing companies listed in the Istanbul Stock Exchange. Terzi et al. identified significant differences in a number of accounts in the financial statements, such as inventories, fixed assets, long term liability and net assets. Fitó, Gómez and Moya (2012) analyzed the determinants of companies that decided to choose early transition in Spain as well as the consequences of this choice on main accounting figures and ratios. In their study they determined the main characteristics of companies choosing voluntarily to make the early transition and analyzed the impact of the adoption of the new IFRS Spanish Accounting Standards, in order to ascertain whether or not the transition has significant consequences on financial statements. The study was based on all separate company statements of quoted companies in Spain for 2008 and on the separate statements of quoted companies in Spain that chose 1 January 2007 as their transition date. Their results showed a significant change in the accounting figures and ratios.

Jaruga, Fijalkowska, Jaruga-Baranowska, and Frendzel (2007) and Krzywda and Schroeder (2007) examined the implementation of IFRS in Poland. Jaruga et al. focused on the impact of IFRS adoption on income and equity, by performing a close analysis of 225 financial reports ( 171 consolidated) of companies listed in the Warsaw Stock Exchange. Krzywda and Schroeder analyzed qualitative and quantitative differences between Polish accounting regulations that had been disclosed by sample of entities listed in the same stock exchange for the years ending 31 December 2001, 2003 and 2004. Jaruga et al. identified areas with significant changes such as property, plant and equipment, goodwill and negative goodwill, recognition and measurement of revenues, share based - payment, financial instruments and hedging, intangible assets, business combinations, leasing and investment properties. Similarly, Krzywda and Schroeder noted that the book value of net assets for 2004 which was calculated according to Polish accounting regulations was understated by an average of between $6 \%$ and $9 \%$ while post tax earnings for 2004 were understated by an average $35 \%$.

Ormrod and Taylor (2004) and Aisbitt (2006) examined the effect of IFRS adoption in the UK. Ormrod and Taylor studied the potential consequences on corporate debt covenants of companies in the UK debt market that are subject to impending change to IFRS. Their discussion had both a particular reference to the UK and across the EU. Ormrod and Taylor reviewed the evidence on the accounting basis of debt covenants, IFRS and debt contracts, in order to consider the impact of accounting regulatory change on debt covenants. Furthermore, they discussed IFRSs and earnings volatility as well as International Accounting Standards Board implementation strategy and its implications for uncertainty. Additionally, they considered the impact of IFRS on debt covenants and examined problems that would arise from IFRS to restate liabilities. Finally, they discussed provisions for first time adoption of IFRS. Aisbitt analyzed the reconciliations of equity presented as part of the transition from UK GAAP to IFRS by the largest UK companies that formed the UK's FTSE 100 index on 1st January, 2005. The data used in the investigation were "hand collected" from the published reconciliations of balance sheets published in UK rules to the balance sheets restated under IFRS. The reconciliations reported in the specific paper were the most up - to - date published at the beginning of May 2006. Both studies argued that the adoption of IFRS has a significant impact on the examined financial information and financial analysis.

Delvaille, Ebbers, and Saccon (2005) compared the developments in France, Germany and Italy and the approaches to integrate the current European accounting reform process with IFRS. The countries selected for the specific study were opposite from the Anglo-Saxon approach to accounting and the authors' aim was to analyze the ways these countries adopted EU strategy of convergence of IFRS. During their research, they described the regulatory accounting changes that were taking place in the three countries and further evaluated the impact of those changes on reporting practice based on the empirical research of accounting rules applied in its consolidated financial statements and individual accounts, as well. Moreover, the authors analyzed the environmental factors for change and the motives for differences and similarities in the French, German and Italian approach of convergence of IFRS. According to their view, the adoption of IFRS in individual accounts seems to have more disadvantages for European companies in general, as IFRSs are not designed for tax accounts or dividend payment, in particular for smaller companies.

Weibenberger, Stahl and Vorstius (2004) surveyed the motives that led German listed companies to optimize (for international reporting systems (IFRS or US GAAP) rather than German GAAP and considered whether these objectives have been achieved. Their empirical research was based on a survey of listed companies in Germany 
and it was conducted from September 2000 to February 2001. The aim of the research was to consider in detail the objectives German companies had pursued in adopting an international GAAP (IFRS or US GAAP) and to assess whether these objectives had been achieved by the companies. In addition, they analyzed whether the motives for choosing one of the two international reporting systems rather than the other were in accordance with strictly discriminating preferences considering the objectives that motivated the use of particular GAAP regime. The authors concluded, among others, a) that motives were an improved supply of information, b) the diversification and internationalization of the body of investors and c) increased comparability with industry peers. They also stressed out that motives related to operating business aspects played only a minor role in the decision process.

Tendeloo and Vanstraelen (2005) and Callao and Jarne (2010) focused on earnings management. Tendeloo and Vanstraelen addressed the question whether voluntary adoption of IFRS was associated with lower earnings management of German companies while Callao and Jarne focused on whether the adoption of IFRS in EU had increased or decreased the scope of discretionary accounting practices. The research of Tendeloo and Vanstraelen was based on a sample of German listed companies (excluding financial institutions and utility companies), contained 636 firm-year observations for the period 1999-2001. They concluded that when hidden reserves were taken into consideration, IFRS adopters did not present different earnings management behavior compared to companies reporting under German GAAP. Callao and Jarne examined a sample of 1.408 non-financial companies listed in the stock markets in $11 \mathrm{EU}$ member states. This sample was representative of the Anglo-Saxon and Continental accounting systems traditionally identified in Europe (Belgium, Finland, France, Germany, Greece, Italy, Netherlands, Portugal, Spain, Sweden and UK). They concluded that the earnings management had been intensified since the adoption of IFRS in Europe, as discretionary accruals had increased in the period following implementation.

Jermakowicz (2004) carried out a survey on the adoption of IFRS by BEL-20 companies in Belgium, analyzing its consolidated financial statements. The study approached the measurement of the impact, perceived or actual, that the IFRS either already had or would have on Belgium companies' internal organization accounting and financial strategy, as well as the stage in the IFRS implementation process. The survey outcome indicated that implementing IFRS would change dramatically the way these companies design and handle both their internal and external activities while concluded among others that the adoption of IFRS in Belgium would increase the comparability of consolidated accounts as well as the levels of transparency for many companies. Apostolou and Dimitras (2009) examined the differences of the disclosed financial information, in the form of accounting ratios, derived from the companies' financial statements prepared in conformity with Greek GAAP and IFRS. The sample which has been used in this study included all manufacturing firms listed in Athens Stock Exchange at 2005. The authors concluded that the application of IFRS for Greek listed companies had caused changes in the financial statements and consequently in the related accounting ratios. However, the statistical analysis of a set of accounting ratios showed that the differences are not significant for all the ratios.

Brown and Tarca (2005) reviewed and documented existing and proposed enforcement bodies in EU prior to IFRS adoption and identified issues to be resolved in France and Germany, the Netherlands, the UK, in relation to the enforcement of IFRS from 1 January 2005. They concluded, among others, that the adoption of IFRS was supported in many countries because it might improve the quality and international comparability of financial reporting. Horton, Serafeim and Serafeim (2014) examined company's information environment focused on forecast in all countries with I/B/E/S coverage and fiscal years from 2001 to 2007 . The research was based on the test of the differences in forecast errors before and after IFRS mandatory compliance for non-adopters, mandatory adopters and voluntary adopters. In order to support their study, the authors had also calculated the absolute difference between the company's local GAAP earnings for 2004 and the reconciled IFRS earnings for 2004, as a percentage of absolute local results. They noted that mandatory IFRS adoption had improved the quality of information intermediation in capital markets and as a result firm's information environment by increasing both information quality and accounting comparability.

Haller (2002) approached the explanation and reasoning behind past developments and discussed some future prospects of financial reporting within the EU. He concluded that financial statements of listed European companies would be much more comparable in the near future than subsequent to the implementation of the Accounting Directives. Schipper (2005) described several implementation effects associated with the mandated adoption of IFRS in EU, including a possible increased demand for detailed implementation guidance and for a single European securities regulator. She also discussed the mandated adoption as a research setting for considering the relative influences of standards versus incentives as determinants of financial reporting outcomes, defined the boundaries of the reporting entity for consolidation purposes and described the use of fair value as 
well a measurement attribute.

Whittington (2005) discussed the IASB's process of developing accounting standards for adoption by listed companies within the EU. The study was focused on the structure of the IASB, its role as a global standard setter and its program while particular attention was given to accounting for financial instruments and reporting on financial performance. Whittington drew conclusions about the IASB's technical program, the political dimension and the implementation problem and he highlighted that ultimately markets needed full and transparent information, untainted by concessions to vested interests. Finally, Soderstrom and Sun (2007) reviewed the research on the consequences of changing accounting standards and discussed determinants of accounting quality following the IFRS adoption. They concluded that the international accounting literature had generally found a positive impact from voluntary adoption of better accounting principles, IFRS included. They argued that the accounting quality after IFRS adoption hinged on the quality of standards, a country's legal and political system and financial reporting incentives. They further reviewed the accounting, finance and economics literature on these factors with respect to accounting quality and concluded that a country's legal and political system indirectly affects the accounting quality as well.

\section{Differences between IFRS and Greek GAAP}

This brief overview of differences between IFRS and Greek GAAP aims at highlighting the main areas of differentiation in financial statements of the Greek firms that could substantially influence the quality of the historical information which might lead to inappropriate business decisions concerning such entities. The term Greek General Accepted Accounting Standards refers informally to the accounting principles and policies adopted by the Greek statutory accounting framework which is part of the local corporate law, fully incorporated the Fourth and Seventh EU Directives and the Greek Chart of Accounts (P. D. 1123/1980) and also complies with the requirements of the Greek tax legislation (mainly driven by L. 2238/1994 and P. D. 186/1992).

On the first time adoption of IFRS by the Greek listed companies (31.12.2005), significant differences between IFRS and Greek GAAP are primarily noted with respect to the presentation of financial statements. Since 31.12.2005 a full set of statutory financial statements consisted of balance sheet, income statement, statement of distribution of profits and notes. According to Greek GAAP no requirements existed regarding earnings per share, related parties disclosures and segment reporting. On the contrary, prior year revenues and expenses were recognized in the profit and loss of the year and the classification of extraordinary income and expenses in profit and loss was acceptable.

Furthermore, differences were noted with respect to initial recognition, and subsequent measurement of property, plant and equipment. These differences mainly referred to directly attributable costs and government grants. The later, according to Greek GAAP were recognized directly to equity and were subject to amortization. In addition, statutory accounting did not include any accounting policies with respect to investment property, biological assets and mineral resources. Finally, the accounting for leasing (including sales and lease back) was substantially different between IFRS and Greek GAAP. Differences were also identified in accounting for intangible assets and formation expenses. According to statutory accounting a number of items were capitalized as formation expenses in intangible assets including the deferral costs.

The accounting treatment applied by Greek GAAP for post-employment benefits was substantially different as well. Based on this accounting, the provision formed was related to employer obligation to pay severance compensation on employee dismissal, while no classification criteria existed. Further, the amount of estimated compensation was based on the number of years of service and the remuneration on the date of dismissal. Finally, no actuarial methods were applied in the calculation of these liabilities while no actuarial gains or losses were recognized or disclosed in financial statements. Substantial differences were also noted in accounting for provisions and impairment. In statutory accounting framework the issue of impairment was addressed by applying the approach of provisions. No guidance existed on how to determine or calculate impairment.

Another area of differentiation was related to financial assets and liabilities. Greek GAAP had not included any guidance according to accounting treatment and presentation of financial assets and liabilities. In statutory accounting, financial assets were recognized initially at cost. Financial liabilities were only classified as long term and short term items. Fair value measurement for both financial assets and liabilities was not acceptable. Further, the split of compound instruments into their liability and equity components was not required. Derivatives were treated as contracts and were recorded in specific off balance sheet accounts until the derivative instrument expired or was settled. Finally, no guidance existed regarding hedge accounting.

In profit and loss account, we noted substantial differences in revenue recognition (including accounting for construction contracts) and accounting for current and deferred income taxes. Under Greek GAAP revenue 
recognition was mainly driven by the statutory tax legislation. Furthermore, only the income taxes occurred in the current reportable period were charged. In addition, no deferred tax assets or liabilities were recognized and no provision for the unaudited tax years was posted. In terms of presentation, current income taxes were recognized directly to net assets through the statement of distribution of profits.

Finally, substantial differences were identified in consolidated financial statements. These differences were mainly related to the exemptions from consolidation, the accounting for business combinations and the purchase method of accounting, the joint ventures and the SPEs. Statutory accounting adopted the Seventh EU Directive based on which, the calculation, the initial recognition and the subsequent measurement of goodwill (and minority interests) were substantially different compared to IFRS. According to this accounting, goodwill could be recognized directly to equity or alternatively could be amortized in a 5 year period. Negative goodwill was always recognized directly to equity.

\section{Survey Design and Model Selection}

Table 1. Population distribution by sector and subsector

\begin{tabular}{|c|c|c|}
\hline Main Sector & Sub Sectors & Companies \\
\hline Construction and building materials & Construction & 17 \\
\hline \multirow[t]{3}{*}{ Industrial products and services } & Shipping & 1 \\
\hline & Transportation services & 3 \\
\hline & Supporting services to enterprises & 4 \\
\hline Health & Medical services & 6 \\
\hline \multirow[t]{2}{*}{ Media } & Television and entertainment & 3 \\
\hline & Advertising & 1 \\
\hline \multirow[t]{5}{*}{ Travel and Leisure } & Airlines & 1 \\
\hline & Gambling & 2 \\
\hline & Hotels & 4 \\
\hline & Food and beverage & 1 \\
\hline & Travel and leisure & 6 \\
\hline Telecommunications & Telecoms & 2 \\
\hline \multirow[t]{3}{*}{ Public Utilities } & Compatible electricity & 1 \\
\hline & Alternative electricity & 1 \\
\hline & Water Supply & 2 \\
\hline \multirow[t]{4}{*}{ Real Estate Property } & Investments and development in real estate property & 7 \\
\hline & Real Estate Services & 1 \\
\hline & Real Estate Trusts in industrial and commercial premises and properties & 2 \\
\hline & Specialized Real Estate Trusts & 1 \\
\hline \multirow[t]{4}{*}{ Technology } & IT services & 8 \\
\hline & Internet services and supporting & 1 \\
\hline & Software & 5 \\
\hline & STATISTICAL POPULATION & 80 \\
\hline
\end{tabular}

The population under study comprised a total of eighty (80) entities, listed in ASE, for the fiscal year (2004), when their financial statements under both Greek GAAP and IFRS were available. The abovementioned entities were active in nine sectors which in turn were divided into twenty-three (23) subsectors according to the ASE taxonomy (Table 1). The statistical population did not include manufacturing companies dealing with industrial production, purely commercial companies and companies that provide financial services (banks, insurance companies, mutual funds, investment companies, etc.). The main sectors covered by the statistical population 
were the following:

1) Construction and building materials;

2) Industrial products and services (excluding manufacturing enterprises dealing with industrial production);

3) Health;

4) Media;

5) Travel and Leisure;

6) Telecommunications;

7) Public Utilities;

8) Real Estate property;

9) Technology (excluding purely commercial companies).

The statistical population under examination consisted of companies with the following four additive attributes and /or features:

a. They have the legal form of Société Anonyme (Limited Liability Company).

b. Their shares were listed in the Athens Stock Exchange in 2005, first year of mandatory implementation of IFRS by these companies.

c. They are not financial institutions, insurance companies or institutions involved in the broader financial services industry.

d. They are neither manufacturing companies nor purely commercial companies.

Initially, a pilot group of twenty-five (25) entities was randomly selected, upon which two financial ratios were calculated, on the basis of their financial importance. The financial ratios selected during the pilot phase were general liquidity and net assets to total liabilities. Setting the desired level of accuracy at $10 \%$ for both financial ratios and taking into account the correction term $1-(\mathrm{n} / \mathrm{N})$, it was calculated that a sample of size fifty $(\mathrm{n}=50)$ should be drawn from the population of eighty $(\mathrm{N}=80)$ companies.

A sample of that size produced estimates for the current ratio and the debt to equity ratio with an accuracy of $12 \%$ and $8 \%$ respectively, achieving the desired average accuracy of $10 \%$. Then, the initial randomly selected sample of twenty-five (25) entities was supplemented by another twenty-five (25) randomly selected ones, resulting in a total sample of fifty (50) entities.

Our study focused on the examination of twenty-three (23) frequently used financial ratios (alternatively "ratios") to identify the effects of differences by using two different accounting frameworks. The specific financial ratios were selected because of their importance on economic decision-making. Further, they contained a high degree of sensitivity to differences in accounting frameworks that were the basis for the preparation of the financial statements from which these financial ratios had been derived (Table 2).

Table 2. Financial ratios-statistical variables

\begin{tabular}{ll}
\hline & Liquidity Ratios \\
\hline D1 & Current Assets / Short Term Liabilities \\
D2 & (Current Assets - Inventories) / Short Term Liabilities \\
\hline & Activity Ratios \\
\hline D3 & Sales / Trade Receivable \\
D4 & Sales / Working Capital \\
D5 & Net Profits / Working Capital \\
D6 & Sales / Total Assets \\
D7 & Sales / Tangible Assets \\
D8 & Sales / Net Assets \\
\hline
\end{tabular}




\begin{tabular}{ll}
\hline & Profitability Ratios \\
\hline D9 & Gross Profits / Sales \\
D10 & Net Profits / Sales \\
D11 & Net Profits / Total Assets \\
D12 & Gross Profits / Total Assets \\
D13 & Net Profits / Net Assets \\
D14 & EBITDA / Net Assets \\
\hline & Financial Structure and Viability Ratios \\
\hline D15 & Net Assets / Total Liabilities \\
D16 & Net Assets / Tangible Assets \\
D17 & Net Assets / Total Assets \\
D18 & Tangible Assets / Total Assets \\
D19 & Total Liabilities / Total Assets \\
D20 & Short Term Liabilities / Net Assets \\
D21 & Long Term Liabilities / Net Assets \\
D22 & EBIT / Interest expense \\
\hline & Operating Expense Ratios \\
\hline D23 & Cost of sales + Operating Expenses / Sales \\
\hline
\end{tabular}

\section{Statistical Methodology and Results}

\subsection{Methodology}

Our dataset includes twenty three variables corresponding to selected ratios under IFRS $\left(X_{j}, j=1, \ldots, 23\right)$ paired with the corresponding ratios under Greek GAAP $\left(\mathrm{W}_{\mathrm{j}}\right)$. In order to test the normality of the empirical distribution functions of $D_{j}=X_{j}-W_{j}, j=1, \ldots, 23$, based on the random sample of $n=50$ entities, we performed a sequence of Kolmogorov-Lilliefors goodness of fit test for families of distributions. The normality test was based on the Lilliefors test statistics $\mathrm{T}=\sup |\mathrm{F}(\mathrm{z})-\mathrm{S}(\mathrm{z})|$ where $\mathrm{F}(\mathrm{z})$ stood for the standard normal distribution function, and $\mathrm{S}(\mathrm{z})$ the empirical distribution function of the standardized data values. The test rejected the hypothesis of normality whenever $\mathrm{T}$ exceeded its 1-a quintile, where a, was the level of significance for the test. Running the test for all 23 variables, it came out that none of them followed the normal distribution at a=0.05 level of significance and this also held for all but $\mathrm{D}_{9}$ at $\mathrm{a}=0.01$ (Table 3 ). Therefore a nonparametric approach adopted in both descriptive (Table 4) and inferential analysis.

Table 3. Statistical hypothesis testing

\begin{tabular}{ccc}
\hline Variables & $\begin{array}{c}\text { Lilliefors Test for Normality } \\
\mathrm{p} \text {-values (significance) }\end{array}$ & $\begin{array}{c}\text { Wilcoxon sign-rank test } \\
\mathrm{p} \text {-values (significance) }\end{array}$ \\
\hline D1 & $<0.01(* * *)$ & $0.067(*)$ \\
D2 & $<0.01(* * *)$ & $0.093(*)$ \\
D3 & $<0.01(* * *)$ & $0.013(* *)$ \\
D4 & $<0.01(* * *)$ & 0.609 \\
D5 & $<0.01(* * *)$ & $0.074(*)$ \\
D6 & $<0.01(* * *)$ & 0.721 \\
D7 & $<0.01(* * *)$ & $0.030(* *)$ \\
D8 & $<0.01(* * *)$ & 0.671 \\
D9 & $0.028(* *)$ & 0.639 \\
\end{tabular}




\begin{tabular}{lcc}
\hline D10 & $<0.01(* * *)$ & 0.349 \\
D11 & $<0.01(* * *)$ & 0.101 \\
D12 & $<0.01(* * *)$ & 0.841 \\
D13 & $<0.01(* * *)$ & $0.019(* *)$ \\
D14 & $<0.01(* * *)$ & 0.963 \\
D15 & $<0.01(* * *)$ & $0.008(* * *)$ \\
D16 & $<0.01(* * *)$ & $0.008(* * *)$ \\
D17 & $<0.01(* * *)$ & $0.013(* *)$ \\
D18 & $<0.01(* * *)$ & $0.002(* * *)$ \\
D19 & $<0.01(* * *)$ & $0.009(* * *)$ \\
D20 & $<0.01(* * *)$ & 0.315 \\
D21 & $<0.01(* * *)$ & $<0.01(* * *)$ \\
D22 & $<0.01(* * *)$ & 0.529 \\
D23 & $<0.01(* * *)$ & 0.772 \\
\hline
\end{tabular}

Note: $(*)$ Significant at level $\mathrm{a}=0.10 ;(* *)$ significant at level $\mathrm{a}=0.05 ;(* * *)$ significant at level $\mathrm{a}=0.01$.

Table 4. Summary statistics on differences

\begin{tabular}{cccccccc}
\hline VAR & Min & Q1 & Median & Q3 & Max & Range & IQR \\
\hline D1 & -11.997 & -0.455 & -0.089 & 0.167 & 11.167 & 23.164 & 0.622 \\
D2 & -11.997 & -0.386 & -0.043 & 0.164 & 11.167 & 23.164 & 0.550 \\
D3 & -16.03 & -0.04 & 0.15 & 0.70 & 69.82 & 85.84 & 0.75 \\
D4 & -59.23 & -0.82 & 0.07 & 1.16 & 51.12 & 110.35 & 1.98 \\
D5 & -3.112 & -0.405 & -0.020 & 0.037 & 7.786 & 10.898 & 0.442 \\
D6 & -0.5084 & -0.0958 & 0.0000 & 0.0753 & 0.3845 & 0.8929 & 0.1711 \\
D7 & -16.79 & -0.45 & -0.05 & 0.08 & 67.96 & 84.75 & 0.53 \\
D8 & -12.542 & -0.184 & 0.003 & 0.291 & 1.574 & 14.116 & 0.475 \\
D9 & -0.1801 & -0.0318 & 0.0000 & 0.0229 & 0.1906 & 0.3708 & 0.0547 \\
D10 & -0.4898 & -0.0373 & -0.0051 & 0.0199 & 2.5374 & 3.0272 & 0.0572 \\
D11 & -0.2005 & -0.0233 & -0.0043 & 0.0095 & 0.0720 & 0.2725 & 0.0328 \\
D12 & -0.1602 & -0.0266 & 0.0040 & 0.0201 & 0.0893 & 0.2495 & 0.0467 \\
D13 & -1.8328 & -0.0887 & -0.0112 & 0.0135 & 0.1912 & 2.0240 & 0.1022 \\
D14 & -2.8114 & -0.0348 & -0.0010 & 0.0380 & 0.5921 & 3.4035 & 0.0728 \\
D15 & -4.68 & -0.58 & -0.12 & 0.02 & 60.58 & 65.26 & 0.60 \\
D16 & -13.002 & -0.507 & -0.081 & 0.032 & 8.317 & 21.318 & 0.539 \\
D17 & -0.3077 & -0.0811 & -0.0368 & 0.0068 & 0.3035 & 0.6112 & 0.0879 \\
D18 & -0.1348 & -0.0146 & 0.0299 & 0.1203 & 0.7542 & 0.8890 & 0.1349 \\
D19 & -0.0063 & -0.3035 & 0.0368 & 0.0811 & 0.3077 & 0.6112 & 0.0874 \\
D20 & -3.664 & -0.147 & 0.013 & 0.315 & 2.048 & 5.712 & 0.461 \\
D21 & -0.494 & 0.011 & 0.058 & 0.207 & 4.032 & 4.526 & 0.196 \\
D22 & -688.9 & -2.0 & 0.3 & 6.3 & 1139.4 & 1828.3 & 8.3 \\
D23 & -0.3077 & -0.0315 & -0.0000 & 0.0317 & 0.2820 & 0.5897 & 0.0632 \\
\hline & & & & & & & \\
\hline
\end{tabular}


The Wilcoxon signed - rank test had been chosen to examine the hypothesis that the expected values of the differences, $E\left(D_{j}\right)$ were significantly different than zero or not. The test was based on the calculation of the ranks of the absolute differences for each of the 23 variables and therefore was quite robust concerning the basic assumptions of a matched pair test. The null hypothesis $\mathrm{H}_{0}$ : Median (D) $=0$ was rejected in favor of a two tailed alternative at $\mathrm{a}=0.05$ level when $|\mathrm{W}|>\mathrm{W}_{1-\alpha / 2}$, otherwise $\mathrm{H}_{0}$ was accepted. W stood for Wilcoxon signed-rank test statistics and $\mathrm{W}_{1-\alpha / 2}$ was the corresponding quintile of its distribution. The results of the Wilcoxon signed-rank test (see also Table 3) indicated that, statistically significant differences in financial ratios, measured by the variables $D_{i}, i=1 \ldots 23$, occurred in different levels of significance as follows:

\subsection{Results Significant at $a=0,01$}

Variable D15, corresponding to Net Assets/Total Liabilities, showed a significant negative median difference. This suggested that the values of the ratio under IFRS $(\mathrm{Xj})$ were lower in general than those under GAAP $(\mathrm{Wj})$, which was due to an overestimation of net assets and/or an underestimation of liabilities, under Greek GAAP.

Variable $\mathrm{D}_{16}$, corresponding to Net Assets/Tangible Assets, showed a negative Median difference. This suggested that the values of the ratio under IFRS $\left(\mathrm{X}_{\mathrm{j}}\right)$ were lower in general than those under Greek GAAP $\left(\mathrm{W}_{\mathrm{j}}\right)$ which was due to an overestimation of the Net Assets, under Greek GAAP.

Variable $\mathrm{D}_{18}$, corresponding to Tangible Assets/Total Assets showed a positive Median difference. This suggested that the values of the ratio under IFRS $\left(\mathrm{X}_{\mathrm{j}}\right)$ were higher in general than those under Greek GAAP $\left(\mathrm{W}_{\mathrm{j}}\right)$, which was due to a higher value of tangible assets under IFRS financial statements, in the context of the first time adoption of IFRS, pursuant to IFRS 1.

Variable $\mathrm{D}_{19}$, corresponding to Total Liabilities/Total Assets showed a positive Median difference. This suggested that the values of the ratio under IFRS $\left(X_{j}\right)$ were higher in general than those under Greek GAAP $\left(W_{j}\right)$ which was due to an underestimation of total liabilities, under Greek GAAP.

\subsection{Results Significant at $a=0,05$}

Variable $\mathrm{D}_{3}$, corresponding to Sales/Trade Receivables, showed a positive Median difference. This suggested that the values of the ratio under IFRS $\left(\mathrm{X}_{\mathrm{j}}\right)$ were higher in general than those under Greek GAAP $\left(\mathrm{W}_{\mathrm{j}}\right)$, which was due to an overestimation of trade receivables when the financial statements had been prepared under Greek GAAP.

Variable $\mathrm{D}_{7}$, corresponding to Sales/Tangible assets, showed a negative Median. This suggested that the values of ratio under IFRS $\left(\mathrm{X}_{\mathrm{j}}\right)$ were lower than those under Greek GAAP $\left(\mathrm{W}_{\mathrm{j}}\right)$ which was due to a higher value of tangible assets under IFRS, in the context of the first time adoption of IFRS, pursuant to IFRS 1 (see also our reference in $\mathrm{D}_{18}$ above).

Variable $\mathrm{D}_{13}$, corresponding to Net Profits/Net Assets, showed a negative Median difference. This suggested that the values of ratio under IFRS $\left(\mathrm{X}_{\mathrm{j}}\right)$ were lower than those under Greek GAAP $\left(\mathrm{W}_{\mathrm{j}}\right)$ which was due to lower net profits in IFRS financial statements.

Variable $\mathrm{D}_{17}$, corresponding to Net Assets/Total Assets showed a negative Median difference. This suggested that the values of ratio under IFRS $\left(\mathrm{X}_{\mathrm{j}}\right)$ were lower than those under Greek GAAP $\left(\mathrm{W}_{\mathrm{j}}\right)$, which was due to an overestimation of Net Assets under Greek GAAP.

\subsection{Results Significant at $a=0,10$}

Variable $\mathrm{D}_{1}$, corresponding to Current Assets / Short Term Liabilities, showed a negative Median difference. This suggested that the values of ratio under IFRS $\left(\mathrm{X}_{\mathrm{j}}\right)$ were lower than those under Greek GAAP $\left(\mathrm{W}_{\mathrm{j}}\right)$, which was due to an overestimation of current assets and/or the underestimation of short term liabilities, under Greek GAAP.

Variable $\mathrm{D}_{2}$, corresponding to (Current Assets-Inventories)/Short Term Liabilities showed a negative Median difference. This suggested that the values of ratio under IFRS $\left(\mathrm{X}_{\mathrm{j}}\right)$ were lower than those under Greek GAAP $\left(\mathrm{W}_{\mathrm{j}}\right)$, which was due to an overestimation of current assets -inventories and/or the underestimation of short term liabilities, under Greek GAAP.

Variable $\mathrm{D}_{5}$, corresponding to Net Profits/Working Capital, showed a negative Median difference. This suggested that the values of ratio under IFRS $\left(\mathrm{X}_{\mathrm{j}}\right)$ were lower than those under Greek GAAP $\left(\mathrm{W}_{\mathrm{j}}\right)$, which was due to lower net profits under IFRS (see also our reference in $\mathrm{D}_{13}$ above).

\section{Conclusions}

IFRS, for Athens Stock Exchange listed companies, were first implemented in Greece in 2005. This development 
concerned not only the adoption and integration of relevant EU provisions in Greek Company Law, but constituted the inevitable outcome of a rather long standing questioning of the quality of historical financial information obtained from financial statements in Greece until 2004. To contribute to our understanding in this crucial area of discussion, we examined whether mandatory IFRS adoption in Greece affected the historical information presented by 23 financial ratios of companies that were active in nine sectors of Athens Stock Exchange.

Statistically significant differences are found in all categories of financial ratios, selected to be examined in the present study, except for one, that of operating expenses. We found that the conversion of statutory financial statements to IFRS had significant impact on historical financial information regarding the financial structure and viability. In this case, the main areas of concern are net assets, tangible assets and total liabilities. Furthermore, we identified significant differences in the financial information of two activity ratios regarding the receivables and tangible assets turnover. Based on the results of our study we noted that the return on net assets has been significantly changed according to IFRS. It could be noted that this is mainly because of differences in trade receivables, tangible assets and net assets. Finally, we identified that the IFRS conversion had significant impact in specific indicators of an entity's liquidity, the current and acid test that is mainly explained by the differences between IFRS and Greek GAAP in current assets and short term liabilities.

The financial analysis that would be based on the aforementioned ratios of liquidity, activity, profitability as well as financial structure and viability could lead to substantially different results if the ratios were calculated according to financial statements prepared under IFRS or Greek GAAP. In most cases in which statistically significant differences were found, it was observed that the financial information related to trade receivables, net profits and net assets under Greek GAAP seemed to be overestimated while short and long term liabilities were underestimated. Substantial differences identified in ratios in which tangible assets consists a significant component could be explained by the higher values according to which these assets were presented in IFRS financial statements under first time adoption. We found no significant differences in three activity ratios (working capital turnover, total assets turnover and owner's equity turnover). So is the case for the majority of profitability ratios (gross profit margin, net profit margin, return on total assets), in two financial structure and viability ratios (short term liabilities to net assets and EBIT to interest expense) and the operating expense ratio (total expenses to sales).

Furthermore, the mandatory conversion from Greek GAAP to IFRS allowed for the Greek listed entities, a one-time opportunity to reconsider the accounting policies applied for financial reporting purposes. In this paper we highlighted certain changes in accounting policies that substantially affected the respective financial analysis. These accounting policies refer to (a) the accounting for current and deferred income taxes, (b) the accounting and estimation of post-employment benefits, (c) to the accounting for provisions, (d) to the accounting for impairment and (e) the accounting for leasing.

Conclusively, the outcomes of the study indicated that the mandatory transition from Greek GAAP to IFRS by the Greek companies listed in ASE had led to a number of changes in certain crucial areas of financial statements. These changes, consequently, had affected the financial information provided by the relevant activity and liquidity financial ratios as well as the financial structure ratios. Future research might be focused on studying the feasibility of the implementation of IFRS by the Greek small and medium-size companies. Furthermore, certain differences between Greek GAAP and IFRS that were highlighted in this paper would be considered as areas of debate with respect to accounting framework established by the existing Fourth and Seventh EU Directives. To this end, the specific study could be beneficial for the harmonization of accounting in EU.

\section{Acknowledgements}

We would like to thank the editor and the anonymous referees for their constructive comments and suggestions.

\section{References}

Aisbitt, S. (2006). Assessing the effect of the transition to IFRS on equity: The case of the FTSE 100. European Accounting Review, 15(3), 117-133. http://dx.doi.org/10.1080/09638180600920293

Apostolou, A., \& Dimitras, A. (2009). Financial Decision making and the adoption of IFRSs: Evidence from Greek listed firms. SPOUDAI, 59(1-2), 57-84.

Brown, P., \& Tarca, A. (2005). A commentary on issues relating to the enforcement of International Financial Reporting Standards in EU. European Accounting Review, 14(1), 181-212. http://dx.doi.org/10.1080/0963818042000338997

Callao, S., \& Jarne, J. I. (2010). Have IFRS affected earnings management in the European Union? Accounting 
in Europe, 7(2), 159-189. http://dx.doi.org/10.1080/17449480.2010.511896

Delvaille, P., Ebbers, G., \& Saccon, C. (2005). International Financial Reporting Convergence: Evidence from three continental European countries. Accounting in Europe, 2(1), 137-164. http://dx.doi.org/10.1080/09638180500379103

Dritsas, S. (2011). Historical Financial Information: An empirical study on the first time adoption of IFRS in Greece. M.Sc. Thesis, Dept. of Public Administration, Panteion University of Social and Political Studies, Athens, GR.

Fitó, A., Gómez, F., \& Moya, S. (2012). Choices in IFRS adoption in Spain: Determinants and consequences. Accounting in Europe, 9(1), 61-83. http://dx.doi.org/10.1080/17449480.2012.664390

Haller, A. (2002). Financial accounting developments in the European Union: past events and future prospects. European Accounting Review, 11(1), 153-190. http://dx.doi.org/10.1080/09638180220124770

Horton, J., Serafeim, G., \& Serafeim I. (2014). Does Mandatory IFRS adoption improve the information environment? Contemporary Accounting Research (forthcoming). Harvard University DASH. Retrieved from http://nrs.harvard.edu/urn-3:HUL.InstRepos:9887632

International Accounting Standards Board. (2005). International Financial Reporting Standards (IFRSs), including International Accounting Standards (IASs) and Interpretations as at January 2005.

Jaruga, A., Fijalkowska, J., Jaruga-Baranowska, M., \& Frendzel, M. (2007). The Impact of IAS / IFRS on Polish Accounting, Regulations and the practical implementation in Poland. Accounting in Europe, 4(1), 67-68. http://dx.doi.org/10.1080/17449480701308675

Jermakowicz, E. K. (2004). Effects of Adoption of International Financial Reporting Standards in Belgium: The evidence from BEL -20 companies. Accounting in Europe, 1(1), 51-70. http://dx.doi.org/10.1080/0963818042000270811

Krzywda, D., \& Schroeder, M. (2007). An analysis of the differences between IFRS and Polish Accounting Regulations: Evidence from the Financial Statements of Listed Entities on the Warsaw Stock Exchange for the calendar years ending 2001, 2003 and 2004. Accounting in Europe, 4(1), 79-107. http://dx.doi.org/10.1080/17449480701343060

Ormrod, P., \& Taylor, P. (2004). The impact of the change to International Accounting Standards on Debt Covenants: A UK perspective. Accounting in Europe, 1(1), 71-94. http://dx.doi.org/10.1080/0963818042000262775

Schipper, K. (2005). The introduction of International Accounting Standards in Europe: Implications for international convergence. European Accounting Review, 14(1), 101-126. http://dx.doi.org/10.1080/0963818042000338013

Soderstrom, N. S., \& Sun, K. J. (2007). IFRS adoption and accounting quality: A review. European Accounting Review, 16(4), 675-702. http://dx.doi.org/10.1080/09638180701706732

Tendeloo, B., \& Vanstraelen, A. (2005). Earnings management under German GAAP versus IFRS. European Accounting Review, 14(1), 155-180. http://dx.doi.org/10.1080/0963818042000338988

Terzi, S., Oktem, K., \& Sen, I. K. (2013). Impact of Adopting International Financial Reporting Standards: Empirical evidence from Turkey. International Business Research, 6(4), 55-66. http://dx.doi.org/10.5539/ibr.v6n4p55

Weibenberger, B. E., Stahl, A. B., \& Vorstius, S. (2004). Changing from German GAAP to IFRS or US GAAP: A survey of German Companies. Accounting in Europe, 1(1), 169-189. http://dx.doi.org/10.1080/0963818042000262748

Whittington, G. (2005). The adoption of International Accounting Standards in the European Union. European Accounting Review, 14(1), 127-153. http://dx.doi.org/10.1080/0963818042000338022

\section{Notes}

Note 1. For the purposes of this study, IAS was referred alternatively as International Financial Reporting Standards or IFRS.

Note 2. Given the limitation of mandatory application of IFRS to companies listed in the Athens Stock Exchange, financial statements, under IFRS and Greek GAAP for the year 2004, were not available in Greece for private or 
small and medium size entities (SMEs).

Note 3. The fiscal year 2005 was selected, as this was the first year that the implementation of IFRS in ASE listed companies became mandatory. In this respect, for the fiscal year 2004, the companies which comprised the statistical population prepared and published a full set of financial statements under Greek GAAP as well as a balance sheet and an income statement under IFRS. Moreover, because of the disclosures required under IFRS 1 for the first time adoption, the necessary financial information for the purposes of this study was available in the form of comparable figures in the IFRS adjustments for that year.

Note 4. For the purposes of this study, the financial information derived from the audit financial statements of 2004, prepared under Greek GAAP, had not been adjusted by the audit modifications stated in the respective audit reports. The companies of our statistical population recorded these audit differences as IFRS adjustments in the comparable figures in the audited IFRS financial statements of 2005. These audit modifications had been taken into account and considered as differences between Greek GAAP and IFRS.

Note 5. This work did not aim at comparing different companies in a single sector in one or more fiscal years. In addition, it did not intend to study a company's performance over time.

\section{Copyrights}

Copyright for this article is retained by the author(s), with first publication rights granted to the journal.

This is an open-access article distributed under the terms and conditions of the Creative Commons Attribution license (http://creativecommons.org/licenses/by/3.0/). 